\title{
PENGARUH PENERAPAN XBRL TERHADAP KETEPATAN WAKTU PELAPORAN KEUANGAN \\ (Studi Empiris pada Indeks LQ45 di Bursa Efek Indonesia Tahun 2016-2018)
}

\author{
Alberth D. Rupang ${ }^{1}$ \\ albetdrupang@gmail.com \\ Dr. Syaikhul Falah, SE., M.Si ${ }^{2}$ \\ Bill J. C. Pangayow, SE., M.Si., Ak., CA ${ }^{3}$ \\ Jurusan Akuntansi, Fakultas Ekonomi dan Bisnis Universitas Cenderawasih
}

\begin{abstract}
This study aims to provide empirical evidence about the effect of XBRL implementation on the timeliness of financial reporting of public companies in Indonesia registered in the LQ45 index. The research method uses panel data with 99 observations from 2016 to 2018. The results show that the implementation of XBRL has a positive and significant impact on the timeliness of financial reporting, in contrast to the Debt to Equity ratio used to control company leverage has a positive and insignificant impact on accuracy financial reporting time, as well as Return on Assets used to control the profitability of the company has no significant effect with a negative impact on the timeliness of financial reporting of public companies in Indonesia that are listed on the LQ45 index.
\end{abstract}

Keyword $\quad$ :XBRL, Timeliness of Financial Reporting, DER, ROA, LQ45 Index

\section{PENDAHULUAN}

Pesatnya perkembangan teknologi secara tidak langsung mendorong untuk memperbaharui format laporan keuangan elektronik yang lebih baik, eXtensible Reporting Business Lenguage (XBRL) Merupakan Format data dan bahasa Laporan keuangan yang baru, yang mempermudah pertukaran data secara otomatis, mempercepat proses pencarian, proses analisis dan keakuratan informa (Nurhasanah \& Harahap, 2018). Dengan adanya XBRL maka format tradisional seperti PDF dan HTML perlahan ditinggalkan karena pertukaran data tidak dapat langsung dipakai pada software analisis secara otomatis. Terlepas dari manfaat yang disebutkan di atas, memanfaatkan keuangan perusahaan dan Informasi bisnis yang disediakan dalam format HTML atau PDF di situs web perusahaan atau situs regulator dapat membutuhkan pemotongan biaya dan pemalsuan laporan yang mahal dan rawan kesalahan ( $\mathrm{Ra} \&$ Lee, 2018).

XBRL dikembangkan pada tahun 1998 oleh Charles Hoffman, dan pada tahun 2002 XBRL International, Inc didirikan. Teknologi XBRL tidak hanya mengintegrasikan informasi keuangan yang kompleks, tetapi juga membantu dalam analisis data laporan keuangan dan non-keuangan untun investor, pemegang obligasi, atau pengguna lain di pasar modal (Chen, Harris, Li, \& Wu, 2015). Amerika mulai menerapkan XBRL secara sukarela pada tahun 2005 dan penerapan wajib pada tahun 2008. Negara di Asia seperti China, Korea dan Singapure sudah mewajibkan penerapan XBRL pada tahun 2009. Indonesia sendiri cukup tertinggal karena pengembangan XBRL pada Bursa Efek Indonesia (BEI) pada tahun 2013 dan pada Agustus 2015 diberlakukan penerapan XBRL pada perusahaan terbuka di Indonesia (Nurhasanah \& Harahap, 2018).

\footnotetext{
${ }^{1}$ Alumni Jurusan Akuntansi FEB Uncen

${ }^{2}$ Dosen Jurusan Akuntansi FEB Uncen

3 Dosen Jurusan Akuntansi FEB Uncen
} 
XBRL adalah bentuk eXtensible Markup Language (XML), bahasa yang memungkinkan data untuk dibagikan di berbagai sistem informasi, terutama Internet. Pada penelitian Callaghan \& Nehmer, (2009) XBRL International, Inc. mulai dikembangkan pada tahun 1998 untuk mencapai tujuannya dan memiliki bahasa standar untuk mendigitalkan laporan bisnis sesuai dengan aturan akuntansi, XBRL terus mempromosikan pengembangan dan penggunaan XBRL terdiri dari hampir 550 perusahaan yang berlokasi di tiqp negara di seluruh dunia. XBRL International sejauh ini telah berhasil, dan adopsi XBRL bisa dibilang merevolusi dunia bisnis. EXtensible Business Reporting Language (XBRL) adalah turunan XML berbasis web nonproprietary yang digunakan untuk menandai data keuangan dan non- keuangan serta memberikan konteksnya (XBRL International, 2000).

Terlepas dari kenyataan bahwa XBRL adalah teknologi yang relatif baru, harapannya adalah perusahaan yang menggunakannya untuk melaporkan keuangannya dapat mengalami banyak manfaat. Penghematan biaya dapat terjadi melalui peningkatan efisiensi dan kemampuan pemrosesan dan penurunan biaya pembukuan. Transparansi yang lebih besar dan peningkatan akses ke data memungkinkan investor untuk menggali keuangan dengan lebih mudah. Ini dapat membantu mengurangi persepsi investor tentang risiko dan ketidakpastian berinvestasi di perusahaan dan membuat mereka lebih cenderung berinvestasi di perusahaan. Ketika perusahaan menyerahkan keuangan mereka di XBRL, itu menunjukkan bahwa mereka berkomitmen untuk transparansi. Banyak pengadopsi awal XBRL juga percaya mereka akan mengalami keuntungan penggerak pertama yang akan memisahkan mereka dari perusahaan lain di pasar mereka (Callaghan \& Nehmer, 2009).

XBRL telah dikembangkan secara khusus untuk pelaporan bisnis dan keuangan. Dari perspektif investor dan pihak lain yang tertarik untuk mengambil informasi keuangan perusahaan, mereka saat ini tidak lagi harus membaca secara manual dan memasukkan data untuk melakukan analisis keuangan karena data interaktif dapat langsung diunduh ke dalam spreadsheet dan diproses oleh aplikasi perangkat lunak (Liu, Luo, Sia, O'Farrell, \& Teo, 2014). Tag atau tanda data memberikan informasi tentang fakta dalam menandai data. Tag peta ke kamus data yang ditentukan dalam taksonomi yang sesuai. XBRL berarti penggunaan kembali data, menghasilkan peningkatan aksesibilitas, interoperabilitas, dan efisiensi, berpotensi menghasilkan penghematan waktu dan biaya yang signifikan untuk organisasi yang mengadopsi (Pinsker \& Li, 2009).

Dengan kemajuan teknologi ini, pengguna informasi sekarang dapat memperoleh akses realtime ke informasi melalui berbagai saluran. Secara khusus, pengguna informasi bergerak dari media berita dan sistem pengungkapan berbasis kertas ke sistem pengakhiran elektronik berbasis Internet, memungkinkan pengungkapan informasi perusahaan diperbarui dan tersedia bagi pihak yang tertarik secara real time. Selain itu, sistem pengungkapan elektronik telah menyebabkan perbaikan inovatif lain di lingkungan informasi pasar modal, yang merupakan pengenalan sistem pengungkapan berbasis XBRL. (Ra \& Lee, 2018).

Satu nilai kunci yang diharapkan dari XBRL adalah pengurangan biaya untuk organisasi. Di satu sisi, XBRL diharapkan dapat mengurangi biaya keuangan pembuatan informasi dengan mengoptimalkan informasi keuangan untuk mesin kreasi, publikasi, penemuan, konsumsi, penggunaan kembali, dan komunikasi. XBRL memfasilitasi produksi dan konsumsi otomatis volume besar informasi kinerja bisnis dengan menggabungkan kedekatan dan jangkauan Web, dengan kemampuan informasi konsumen untuk memasukkan informasi perusahaan langsung ke mereka gudang data dan model keputusan. Banyak yang berharap XBRL berkurang memasukkan kembali 
informasi untuk e-Commerce. XBRL juga dirancang untuk meningkatkan efisiensi, keandalan, dan keakuratan komunikasi elektronik dari data keuangan bisnis yang relatif interaktif. Peningkatan efisiensi, keandalan, dan keakuratan informasi bisnis mengurangi biaya modal (Liu et al., 2014).

XBRL bertujuan untuk meningkatkan kualitas laporan kuangan, XBRL membantu mencapai tujuan pengguna, baik perusahaan, regulator, investor maupun stakeholder lainnya untuk menganalisis informasi secara cepat dan otomatis dalam jumlah yang lebih besar. Sehingga mengurangi waktu, biaya, dan kesalahan yang terlibat dalam proses pelaporan bisnis. XBRL juga menyediakan pertukaran terstruktur dan validasi bisnis pelaporan informasi. Selain itu perlu dipahami bahwa, XBRL bukan merupakan suatu merek software atau aplikasi yang akan menggantikan aplikasi atau sistem yang sudah ada. XBRL bukan suatu standar akuntansi baru, dan dalam penerapannya tidak memerlukan perubahan standar akuntansi yang sudah diterapkan disuatu Negara (Novitasari, 2018).

Dengan menggunakan XBRL maka informasi perusahaan semakin akurat dan cepat untuk dilaporkan. XBRL memfasilitasi komunikasi di pasar dan meningkatkan kualitas keputusan investor. XBRL juga mampu mengidentifikasi, menganalisa dan memfasilitasi penukaran data keuangan perusahaan secara otomatis. Selain itu, XBRL juga meningkatkan kualitas informasi keuangan sehingga lebih berguna dalam pengambilan keputusan dibanding dengan format tradisional (Yoon et al., 2011).

Para peneliti sebelumnya Pinsker \& Li, (2008) Yoon, Zo, \& Ciganek, (2011), O. Z. Li et al., (2012), Hao et al., (2014), Chen et al., (2015) dan Nurhasanah \& Harahap, (2018) menunjukan bahwa dengan penerapan XBRL, laporan keuangan akan tersaji dengan format berstandar global sehingga pengguna khususnya investor dapat lebih fokus terhadap analisis informasi keuangan. Hal ini akan mempengaruhi kecepatan pemrosesan informasi di pasar modal yang memberikan dampak positif berupa kenaikan permintaan dari investor sehingga likuiditas saham meningkat, dan investor mengharapkan imbal balik yang rendah. Selain itu, peningkatan kecepatan pemrosesan informasi di pasar modal akan membuat biaya transaksi menurun. Peranan XBRL yang dapat meningkatkan kualitas laporan keuangan dan menyajikan laporan keuangan terstandarisasi global ini akan membuat investor menilai bahwa perusahaan cenderung kurang berisiko.

Hal yang berbeda ditemukan pada penelitian, Bartley et al., (2011) dan Boritz \& No, (2008) bahwa penerapan XBRL pada awalnya akan menimbulkan isu mengenai kredibilitas dan keandalan dari informasi yang disajikan dalam format XBRL, contohnya tidak mencantumkan catatan atas laporan keuangan, kesalahan (error), kehilangan, dan ketidakakuratan angka. Dengan adanya isu ini, penerapan XBRL justru akan membuat laporan keuangan menurun kualitasnya, sehingga investor tidak akan percaya pada perusahaan tersebut.

Berdasarkan latar belakang diatas, maka rumusan masalah yang akan dibahas adalah Apakah penerapan XBRL secara signifikan berpengaruh terhadap Ketepatan Waktu Pelaporan Keuangan. Penelitian ini mempunyai tujuan untuk menemukan bukti empiris apakah penerapan XBRL mempengaruhi kepatuhan perusahaan yang tercacat pada indeks LQ45 dalam ketepatan waktu penyampaian laporan keuangan.

\section{LANDASAN TEORI}

\subsection{Ketepatan Waktu Pelaporan Keuangan}

Menurut Dwiyanti (2010) bahwa tujuan laporan keuangan adalah menyediakan informasi yang menyangkut posisi keuangan, kinerja, serta perubahan posisi keuangan suatu perusahaan yang bermanfaat bagi sejumlah besar pengguna dalam pengambilan keputusan ekonomi. Informasi yang 
relevan akan bermanfaat bagi para pemakai apabila tersedia tepat waktu sebelum pemakai kehilangan kesempatan atau kemampuan untuk mempengaruhi keputusan yang akan diambil. Tepat waktu diartikan bahwa informasi harus disampaikan sedini mungkin untuk dapat digunakan sebagai dasar untuk membantu dalam pengambilan keputusankeputusan ekonomi dan untuk menghindari tertundanya pengambilan keputusan tersebut. Ketepatan waktu tidak menjamin relevansi, tetapi relevansi informasi tidak dimungkinkan tanpa ketepatan waktu. Informasi mengenai kondisi dan posisi perusahaan harus secara cepat dan tepat waktu sampai ke pemakai laporan keuangan.

Ketepatan waktu merupakan batasan penting pada publikasi laporan keuangan. Akumulasi, peringkasan, dan penyajian selanjutnya informasi akuntansi harus dilakukan secepat mungkin untuk menjamin tersedianya informasi sekarang di tangan pemakai. Ketepatan waktu juga menunjukkan bahwa laporan keuangan harus disajikan pada kurun waktu teratur untuk memperlihatkan perubahan keadaan perusahaan pada gilirannya mungkin akan mempengaruhi prediksi dan keputusan pemakai (Andriana \& Raspati, 2015).

Selaku Regulator Otoritas Jasa Keuangan (2017), menetapkan bahwa keterlambatan terjadi jika perusahaan melaporkan informasi keuangannya setelah tanggal yang ditentukan. Hal ini sesuai dengan peraturan X.K.2 yang diterbitkan Bapepam dan didukung oleh peraturan terbaru Bapepam, X.K.2 denga nomor KEP-343/BL/2011 yang berlaku untuk penyusunan laporan keuangan berkala untuk periode pelaporan yang berakhir atau setelah tanggal 30 Juni 2011, penyampaian laporan tahunan emiten atau perusahaan publik yang diatur dalam peraturan Bepepam X.K.2 tahun 2011.

\subsection{Extensible Business Reporting Language (XBRL)}

\subsubsection{Definisi XBRL}

XBRL (eXtensible Business Reporting Language) dikembangkan oleh Charles Hoffman pada tahun 1998 dengan memanfaatkan XML untuk digitalisasi informasi keuangan (Ilias \& Ghani, 2015). eXtensible Markup Language (XML) merupakan bahasa markup yang lebih maju dibanding dengan Hypertext Markup Language (HTML), dimana HTML hanya menggambarkan data sebagai data itu sendiri, sementara XML dapat menunjukkan arti data tersebut. Contohnya, HTML hanya menggambarkan sebuah angka, sedangkan XML mengidentifikasikan angka tersebut dalam konteks yang lebih spesifik misalnya Nomor Pekerja (Steenkamp \& Nel, 2012). Bagian terpenting dari XML adalah "Extensible" yang berarti para pengguna dapat menentukan sendiri tag data yang sesuai dengan spesifikasi masing-masing pengguna. Bagian terpenting XML ini juga ada pada XBRL, dimana XBRL menyediakan tag untuk setiap item dengan demikian setiap item dapat dibaca secara otomatis oleh komputer dan digabungkan sesuai spesifikasi pengguna baik didalam maupun diluar perusahaan (Arnold, Bedard, Phillips, \& Sutton, 2012).

\subsubsection{Kegunaan dan Manfaat XBRL}

XBRL adalah format baru bagi komunikasi bisnis dan data keuangan secara elektronik,yang memiliki manfaat utama berupa pertukaran data secara otomatis, mempermudah pencarian, mempercepat proses analisis, dan menghasilkan keakuratan informasi sehingga kualitas laporan keuangan meningkat (Liu et al. dan Yoon et al.).Sedangkan menurut Chowdhuri et al. (2014), XBRL memberikan manfaat berupa peningkatan efisiensi, efektivitas dan aksesibilitas informasi keuangan.

Berdasarkan penelitian Pinsker and Wheeler (2009), penerapan XBRL lebih efektif dan efisien dalam pengambilan keputusan karena meningkatkan kemampuan perolehan informasi yang dianggap bermanfaat bagi para non-profesional investor. Hal ini didukung juga oleh penelitian Janvrin, et al., (2013) yang meneliti apakah pengguna laporan keuangan memilih format XBRL untuk menganalisis 
laporan keuangan dibanding format lain yang lebih familiar seperti PDF dan Excel, dan hasilnya adalah mayoritas investor memilih XBRL karena lebih efisien dibanding dengan format lainnya.

Selaras dengan BEI, (2014) yang menyatakan bahwa XBRL adalah teknologi dengan format berstandar global yang dapat meningkatkan kegunaan sistem pelaporan secara elektronik dengan cara menyediakan laporan keuangan yang dapat dipertukarkan secara otomatis, sehingga kecepatan analisis dan pengambilan keputusan meningkat. Hal ini memberikan pengaruh pada penghematan biaya dan peningkatan kualitas informasi keuangan. Dengan format yang berstandar global ini investor luar negeri maupun domestik dapat melakukan analisa secara mandiri serta melakukan perbandingan dengan menggunakan bahasa Indonesia maupun bahasa Inggris, sehingga menambah daya tarik pasar modal Indonesia yang berujung pada naiknya likuiditas saham.

\subsubsection{Perkembangan XBRL di Indonesia}

XBRL sebagai standar format pelaporan bisnis yang telah digunakan secara global memiliki kelebihan yang disadari oleh berbagai institusi di Indonesia termasuk Bank Indonesia dan BEI. Bank Indonesia merupakan organisasi pertama di Indonesia yang menerapkan XBRL. Dimulai pada tahun 2010 dengan dilakukannya penilaian terhadap XBRL sebagai platform pelaporan dalam Laporan Stabilitas Moneter \& Keuangan. Hingga akhirnya pada tahun 2014, Bank Indonesia menentukan Bank Umum Syariah sebagai pilot project atau proyek percontohan untuk membuat Laporan Bank Umum Syariah dalam format XBRL (Nurhasanah \& Harahap, 2018).

BEI menjadi organisasi kedua yang secara resmi meluncurkan penerapan XBRL bagi perusahaan terbuka di Indonesia. Awal Juni 2013 merupakan periode awal BEI dalam mengembangkan taksonomi yang akan digunakan pada proses pelaporan laporan keuangan perusahaan terbuka di Indonesia. Pada 5 Juni 2014, BEI mendapatkan pengakuan dari XBRL International Incorporated (XII) untuk taksonomi yang akan digunakan. Pada Agustus 2014, sistem pelaporan XBRL dikembangkan oleh BEI untuk digunakan oleh perusahaan terbuka dalam penyampaian laporan keuangan secara berkala. Teknologi IDXnet diintegrasikan dengan XBRL sehingga perusahaan terbuka tidak perlu memiliki sistem XBRL terlebih dahulu untuk dapat menyampaikan laporan kepada BEI. Selanjutnya 22 Juni 2015, BEI secara resmi meluncurkan penerapan XBRL bagi perusahaan terbuka di Indonesia dan mewajibkan penyampaian laporan keuangan berbasis XBRL dengan tenggat waktu 1 bulan lebih lama dari kewajiban pelaporan laporan keuangan non-XBRL, dan tidak ada tenggat waktu untuk laporan keuangan tahun 2016 dan seterusnya (BEI, 2014).

\subsubsection{Taksonomi XBRL Indonesia Stock Exchange (IDX)}

Taksonomi Indonesia Stock Exchange (IDX) 2014, dan dikeluarkan pertama kali pada tanggal 30 April 2014. Taksonomi saat ini telah diselesaikan melalui proses tinjauan publik yang dilakukan pada bulan Maret 2014 dan pada tanggal 5 Juni 2014 Taksonomi BEI menerima status pengakuan dari XBRL International dan taksonomi ini adalah taksonomiresmi yang akan digunakan dalam Pelaporan Keuangan oleh Perusahaan Terdaftar dalam format XBRL mulai tahun 2015 (BEI, 2014).

Taksonomi BEI, (2014) dikembangkan dengan mengacu pada Standar Akuntansi Indonesia (PSAK), Standar Akuntansi Keuangan ("IFRS") dan ketentuan Otoritas Jasa Keuangan Indonesia (OJK) yang valid dan relevan, serta mewakili karakteristik dari perusahaan pada tiap sektor dan subsektor industri yang digolongkan oleh BEI. Sektor dan subsektor secara keseluruhan, berdasarkan 
format presentasi laporan keuangan umum, diklasifikasikan ke dalam 8 industri utama yaitu, Industri Umum, Industri Properti, Industri Infrastruktur, Industri keuangan dan syariah, Industri Sekuritas, Industri asuransi, Kontrak Investasi Kolektif, Industri Pembiayaan. Format keseluruhan dari laporan keuangan yang telah disiapkan untuk taksonomi dikembangkan melalui proses pengambilan sampel atas laporan keuangan Perusahaan Tercatat di Bursa Efek Indonesia. Pengambilan sampel diambil dari total 188 Perusahaan Tercatat, atau 35\% dari total populasi Perusahaan Tercatat di BEI. Taksonomi BEI 2014 terdiri dari:

1. Document Entity Information (DEI)

Berisi informasi umum yang dimiliki entitas pelapor dan dokumen yang dilaporkan.

2. Laporan Keuangan

Laporan Posisi Keuangan, Laporan laba bersih Komprehensif, Pernyataan Perubahan Ekuitas, dan Laporan Arus Kas.

\subsubsection{Perbedaan XBRL Dengan Format Pelaporan Data Non-Interaktif}

XBRL sangat berbeda dengan file PDF yang selama ini digunakan pada pelaporan keuangan. Laporan yang dinyatakan dalam XBRL ini dioptimalkan untuk konsumsi komputer (analisis data melalui software computer). Hal ini karena data laporan keuangan dalam bentuk XBRL dapat dengan mudah ditransformasikan kedalam berbagai software komputer. XBRL tidak menghasilkan standar akuntansi tetapi mempromosikan kegunaan standar itu sendiri. Organisasi dapat memanfaatkan XBRL untuk mendefinisikan informasi keuangan dan menghasilkan laporan keuangan dalam berbagai format. Secara teknis, batang tubuh utama XBRL adalah taksonomi XBRL. Sebuah taksonomi pelaporan keuangan bertindak seperti kamus akun dengan hubungan yang ditentukan antar mereka (Ahdan, 2015).

\subsection{Pengembangan Hipotesis}

XBRL adalah format pelaporan baru yang berperan penting dalam pertukaran informasi keuangan secara otomatis. Dengan peran tersebut XBRL dapat meningkatkan kemudahan pencarian, kecepatan, dan keakuratan informasi sehingga kualitas informasi keuangan akan meningkat (Janvrin et al., 2013; Nurhasanah \& Harahap, 2018). Peningkatan kualitas informasi keuangan dalam format XBRL juga didukung oleh penelitian Baldwin \& Trinkle, (2011) dan Birt et al., (2017) yang menyatakan bahwa XBRL meningkatkan kualitas informasi keuangan melalui peningkatan karakteristik kualitatif informasi keuangan yang berguna yaitu relevan, terpaham dan terbanding.

Tidak hanya penghematan biaya transaksi, penerapan XBRL yang mempercepat pelaporan keuangan, berkualitas tinggi dan format berstandar global juga menjadikan ketidakpastian/risiko mengenai kinerja perusahaan dimasa depan berkurang. Disaat risiko yang dihadapi oleh investor menurun, maka tingkat pengembalian yang diminta oleh investor juga menurun. Hal ini akan mendorong biaya modal menjadi lebih rendah Pinsker \& Li, (2008) dan Yoon et al., (2011) juga menegaskan jika perusahaan menyajikan laporan keuangan dengan kualitas tinggi dan format standar maka investor cenderung menilai perusahaan sebagai less-risky. Persepsi investor ini menguntungkan bagi perusahaan karena dapat menyebabkan naiknya likuiditas saham dan turunnya biaya modal perusahaan.

Berdasarkan beberapa penelitian terdahulu diatas, penelitian ini memperkirakan bahwa penerapan XBRL dapat meningkatkan Ketepatan waktu pelaporan keuangan untuk meningkatan kualitas informasi keuangan, penghematan biaya transaksi dan penurunan risiko investasi pada 
perusahaan. Oleh karena itu, penelitian ini mengembangkan hipotesis sebagai berikut:

H1: Penerapan XBRL berpengaruh Positif terhadap Ketepatan Waktu Pelaporan Keuangan.

\section{METODE PENELITIAN}

\subsection{Jenis dan Sumber Data}

Jenis data yang akan dipakai pada penelitian ini yaitu data kuantitatif, yang diukur dengan angka yang ada dalam laporan keuangan yang berbasis XBRL. Penelitian ini menggunakan data sekunder yang merupakan data yang didapatkan dengan cara tidak langsung, melainkan melalui perantara. Adapun sumber data yang akan diambil untuk penelitian ini yaitu data laporan keuangan tahunan perusahaan terbuka di indonesia yang masuk dalam daftar indeks LQ45 yang diperoleh pada website idx.co.id.

\subsection{Populasi dan Sampel}

Populasi pada penelitian ini adalah laporan keuangan tahunan perusahaan yang telah terdaftar secara berturut-turut pada Indeks LQ45 periode 2016-2018. Pemilihan populasi berupa perusahaan masuk deretan Indeks LQ45 dikarenakan 45 perusahaan yang terdaftar pada indeks ini memiliki likuiditas yang tinggi. Saham-saham yang ada dalam indeks LQ45 telah menjadi parameter tingkat likuiditas saham dalam perdagangan yang utama pada perusahaan terbuka di indonesia.

Sedangkan sampel yang digunakan hanya menggambil perusahaan yang berada pada indeks LQ45 selama periode 2016-2018. Sampel dipilih dengan menggunakan metode purposive sampling.

\subsection{Variabel Penelitian}

\subsubsection{XBRL}

Variabel dependen dalam penelitian ini adalah ketepatan waktu, dimana kategori 0 untuk perusahaan yang tidak tepat waktu dan kategori 1 untuk perusahaan yang tepat waktu.

\subsubsection{Ketepatan Waktu Pelaporan Keuangan}

Variabel XBRL merupakan variabel independen dalam penelitian dan menggunakan variabel dummy, dimana nilai minimum sama dengan 0 yang memiliki arti bahwa perusahaan tidak menerapkan XBRL, dan nilai maksimum 1 yang memiliki arti bahwa perusahaan menerapkan XBRL (Nurhasanah \& Harahap, 2018).

\subsubsection{Variabel Kontrol}

\section{Variabel Kontrol Debt to Equity Ratio (DER)}

Variabel Debt to Equity Ratio (DER) adalah variabel yang mengontrol risiko perusahaan, khususnya risiko default, Leverage keuangan yang dihitung dengan membagi total liabilitas dengan total ekuitas pada akhir tahun buku.

\section{Variabel Kontrol Return on Asset Ratio (ROA)}

Variabel Return on Asset (ROA) adalah variabel yang mengontrol tingkat pengembalian yang diberikan perusahaan, dihitung dengan membagi laba bersih tahun berjalan dengan total aset tahun sebelumnya. 


\subsection{Teknik Pengumpulan Data}

Penelitian ini menggunakan data sekunder yang diperoleh dari berbagai sumber antara lain sebagai berikut :

1. Studi literatur untuk memperoleh sumber referensi baik dari jurnal, buku, internet dan sumber lainnya yang dapat diandalkan.

2. Data yang diolah dari Website Bursa Efek Indonesia merupakan data untuk variabel XBRL. Perusahaan yang menerapkan XBRL bernilai 1 dan yang tidak menerapkan XBRL akan bernilai 0 .

3. Data yang diolah pada Website Bursa Efek Indonesia untuk data Variabel Ketepatan Waktu Pelaporan Keuangan. Perusahaan yang melaporkan laporan keuangan dengan tepat waktu akan bernilai 1 dan perusahaan yang tidak tepat waktu akan bernilai 0 .

4. Data Laporan Keuangan Tahunan Perusahaan yang terdaftar berturut-turut pada Indeks LQ45 periode 2016-2018.

\subsection{Analisis Regresi Logistik}

Ghozali, (2015) berpendapat pada dasarnya analisis regresi adalah studi mengenai ketergantungan variabel dependen (terikat) dengan satu atau lebih variabel independen (bebas), dengan tujuan untuk mengestimasi dan memprediksi rata-rata populasi atau nilai rata- rata variabel dependen berdasarkan nilai variabel independen yang diketahui.Hasil Analisis Regresi adalah berupa berupa koefisien untuk masing masing variabel independen. Koefisien ini diperoleh dengan cara memprediksi nilai variabel dependen dengan suatu persamaan. Analisis yang digunakan dalam penelitian ini adalah analisis regresi logistik (logistic regression), yaitu untuk melihat pengaruh penerapan XBRL dengan variabel kontrol DER dan ROA terhadap Ketepatan waktu Pelaporan keuangan pada perusahaan yang terdaftar pada Indeks LQ45 Bursa Efek Indonesia periode 20162018. Persamaan Model Regresi yang digunakan adalah sebagai berikut :

$$
\operatorname{Ln}\left(\begin{array}{c}
K W \\
1-K W
\end{array}\right) i t=\beta 0+\beta 1 X B R L i t+\beta 2 D E R i t+\beta 3 R O A i t+e i t
$$

\footnotetext{
Dimana :

$\operatorname{Ln}\left(\frac{K W}{1-K W} \quad i t=\begin{array}{l}\text { Dummy variabel ketepatan waktu (kategori } 0 \text { untuk perusahanyang tidak } \\ \text { tepat waktu dan kategori } 1 \text { untuk perusahaan yang tepat waktu). }\end{array}\right.$
}

$\mathrm{XBRL}_{\mathrm{it}}=$ Dummy variabel XBRL (kategori 1 jika perusahaan menerapkan XBRL dan 0 untuk lainnya).

$\mathrm{DER}_{\mathrm{it}}=$ Debt to Equity Ratio yang dihitung dengan membagi total liabilitas dengan total ekuitas pada akhir tahun buku.

$\mathrm{ROA}_{\mathrm{it}}=$ Return on Asset yang dihitung dengan membagi laba bersih tahun berjalan dengan total aset tahun sebelumnya 


\subsection{Pengujian Hipotesis}

Pengujian dengan model regresi logistik digunakan dalam penelitian ini adalah untuk mengetahui pengaruh dari masing-masing variabel independen terhadap variabel dependen. Kriteria pengujian tingkat kepercayaan yang digunakan adalah $95 \%$ atau taraf signifikasi $5 \%(\alpha=0,05)$. Kriteria penerimaan atau penolakan hipotesis didasarkan pada signifikansi p-value.

Jika nilai probabilitas (sig) $<\alpha=5 \%$ maka hipotesis diterima. Jika nilai probabilitas (sig) $>\alpha$ $=5 \%$ maka hipotesis ditolak.

\section{HASIL DAN PEMBAHASAN}

\subsection{Deskriptif Objek Penelitian}

Populasi pada penelitian ini terdiri dari perusahaan terbuka yang terdaftar di Indeks LQ45 BEI. Jumlah perusahaan yang menjadi populasi dalam penelitian ini adalah 33 perusahaan pada tahun 2016 sampai tahun 2018 sehingga jumlah observasi penelitian sebanyak 99. Dari populasi tersebut digunakan metode purposive sampling untuk mendapatkan sampel dalam penelitian ini. Kriteria sampel penelitian adalah terdaftar secara berturut-turut di indeks LQ45 Bursa Efek Indonesia (BEI) selama periode 2016 sampai dengan 2018, memiliki saham aktif yang diperdagangkan selama periode 2016 sampai dengan 2018 dan menyediakan data yang dibutuhkan dalam penelitian secara lengkap. Prosedur pemilihan sampel dapat dilihat pada Tabel 1.

Tabel 1

Prosedur Pemilihan Sampel

\begin{tabular}{|l|c|}
\hline \multicolumn{1}{|c|}{ Pemilihan Sampel } & \multicolumn{1}{|c|}{$\begin{array}{c}\text { Jumlah } \\
\text { Perusahaan }\end{array}$} \\
\cline { 2 - 3 } & $2016-2018$ \\
\hline Perusahaan Terdaftar di Indeks LQ45 BEI & 45 \\
\hline $\begin{array}{l}\text { Perusahaan yang tidak berturut-turut terdaftar pada Indeks } \\
\text { LQ45 BEI 2016-2018 }\end{array}$ & $(9)$ \\
\hline $\begin{array}{l}\text { Perusahaan yang belum melaporkan laporan keuangan tahun } \\
\text { 2018 per tanggal 1 Mei 2018 }\end{array}$ & $(3)$ \\
\hline $\begin{array}{l}\text { Perusahaan yang secara berturut-turut terdaftar pada Indeks } \\
\text { LQ45 periode 2016-2018 }\end{array}$ & 33 \\
\hline Jumlah Sampel Peelitian & 33 \\
\hline Tahun Pengamatan & $\mathbf{9 9}$ \\
\hline Jumlah Observasi Model & 3 \\
\hline
\end{tabular}

Sumber: Penulis (2019).

Adapun pengambilan sampel penelitian dilakukan dengan menggunakan metode purposive sampling. Dari hasil pemilihan sampel yang sesuai dengan kriteria diatas, maka menghasilkan sampel sebanyak 33 perusahaan sebagai berikut : 


\subsection{Analisis Statistik Deskriptif}

Analisis statistik deskriptif memberikan gambaran atau deskripsi suatu data yang dilihat dari nilai rata rata (mean), standart deviasi (standart deviation), prsentase dan maksimum - minimum. Berikut ini hasil statistik deskripstif dalam penelitian ini:

Tabel 2

Hasil Analisis Statistik Deskriptif

\begin{tabular}{|c|c|c|c|c|c|}
\hline $\begin{array}{c}\text { Variabel Non } \\
\text { Dummy }\end{array}$ & $\mathbf{N}$ & Minimum & Maximum & Mean & $\begin{array}{c}\text { Std. } \\
\text { Deviation }\end{array}$ \\
\hline DER & 99 & 0,15 & 11,06 & 1,9945 & 2,22176 \\
\hline ROA & 99 & $-0,02$ & 0,48 & 0,0936 & 0,09975 \\
\hline $\begin{array}{l}\text { Valid N } \\
\text { (listwise) }\end{array}$ & 99 & & & & \\
\hline Variabel & T & 20 & 2018 & \multirow{2}{*}{\multicolumn{2}{|c|}{$\%$ Total Nilai }} \\
\hline Dummy & $\mathbf{N}$ & Nilai = 1 & Nilai $=0$ & & \\
\hline KW & 99 & $62 \%$ & $38 \%$ & \multicolumn{2}{|c|}{$100 \%$} \\
\hline XBRL & 99 & $78 \%$ & $22 \%$ & \multicolumn{2}{|c|}{$100 \%$} \\
\hline
\end{tabular}

Sumber: SPSS 25 (2019).

Tabel 3

Frekuensi Variabel Ketepatan Waktu Pelaporan Keuangan dan XBRL

\begin{tabular}{|c|c|c|c|c|c|c|}
\hline Variabel & $\mathbf{N}$ & Pengukuran & $\mathbf{2 0 1 6}$ & $\mathbf{2 0 1 7}$ & $\mathbf{2 0 1 8}$ & Total \\
\hline \multirow{2}{*}{ KW } & \multirow{2}{*}{99} & 1 = Perusahaan Tepat Waktu & 2 & 29 & 30 & 61 \\
\cline { 3 - 7 } & & 0 = Perusahaan Tidak Tepat Waktu & 31 & 4 & 3 & 38 \\
\hline \multicolumn{2}{|c|}{ Jumlah } & $\mathbf{3 3}$ & $\mathbf{3 3}$ & $\mathbf{3 3}$ & $\mathbf{9 9}$ \\
\hline \multirow{2}{*}{ XBRL } & \multirow{2}{*}{99} & 1 = Perusahaan Menerapkan XBRL & 14 & 32 & 31 & 77 \\
\cline { 3 - 7 } & & 0 = Perusahaan Tidak Menerapkan XBRL & 19 & 1 & 2 & 22 \\
\hline \multicolumn{2}{|c|}{ Jumlah } & $\mathbf{3 3}$ & $\mathbf{3 3}$ & $\mathbf{3 3}$ & $\mathbf{9 9}$ \\
\hline
\end{tabular}

Sumber: Penulis (2019).

Hasil statistik deskriptif pada Tabel 3 dan Tabel 4 menunjukkan bahwa variabel dependen Ketepatan Waktu Pelaporan Keuangan (KW) mencerminkan perusahaan yang melaporkan laporan keuangan tepat waktu pada tahun 2016 sampai dengan 2018. Variabel ini menggunakan variabel dummy, dimana nilai minimum sama dengan 0 yang memiliki arti perusahaan terlambat melaporkan laporan keuangan, dan nilai maksimum 1 yang memiliki arti bahwa perusahaan tepat waktu dalam melaporkan laporan keuangan. Pada tahun 2016 terdapat sebanyak 2 perusahaan sedangkan pada 
tahun 2017 dan 2018 sebanyak 29 dan 30 perusahaan yang tepat waktu. Pada Tahun 2016, 2017 dan 2018 terdapat sebanyak 31, 4 dan 3 perusahaan yang terlambat dalam melaporkan laporan keuangan tahunannya pada Bursa Efek Indonesia.

Variabel Penerapan XBRL (XBRL) mencerminkan perusahaan yang mengadopsi XBRL pada tahun 2016 sampai dengan 2018. Pada Tabel 3 menunjukan persentase perusahaan yang menerapkan XBRL tahun 2016 sampai dengan 2018 sebanyak 78\% dan sisanya sebanyak 22\% adalah perusahaan yang tidak menerapkan XBRL pada laporan keuangan yang di publikasikan pada Bursa Efek Indonesia. Pada Tabel 4 terdapat 14, 32 dan 31 perusahaan yang menerapkan XBRL padah tahun 2016, 2017 dan 2018. Terdapat 19, 1 dan 2 perusahaan yang tidak menerapkan XBRL pada tahun 2016, 2017 dan 2018. Namun demikian terlihat peningkatan penerapan XBRL dari tahun 106 menunjukan peningkatan meskipun pada tahun 2018 mengalami penurunan 1 perusahaan yang tidak menerapkan XBRL.

Variabel kontrol DER adalah variabel debt to equity ratio yang mengontrol risiko perusahaan, khususnya risiko default. Variabel DER memiliki nilai rata-rata sebesar 1.9945, nilai minimum sebesar 0.15, nilai maksimum sebesar 11.06, dan nilai standar deviasi sebesar 2.22176.

Variabel kontrol ROA adalah variabel return on asset yang mengontrol tingkat pengembalian yang diberikan perusahaan. Variabel ROA memiliki nilai rata-rata sebesar 0.0936, nilai minimum sebesar -0.02, nilai maksimum sebesar 0.48, dan nilai standar deviasi sebesar 0.09975.

\subsection{Menilai Keseluruhan Model (Overall Model Fit)}

Langkah kedua adalah menilai keseluruhan model regresi. Tabel 5 menunjukkan uji kelayakan dengan memperhatikan angka pada -2 Log Likelihood (-2 LL) Block Number $=0$ dan -2 LL Block Number $=1$. Pada tabel tersebut terlihat bahwa angka awal -2 LL Block Number $=0$ adalah 132.755 sedangkan angka -2 LL Block Number $=1$ adalah 98.654.

Tabel 4

\begin{tabular}{|c|c|}
\hline \multicolumn{2}{|c|}{ Overall Fit Model Test } \\
\hline Block Number $=0$ & Block Number $=1$ \\
-2 Log Likelihood & -2 Log Likelihood \\
\hline 132,755 & 98,654 \\
\hline
\end{tabular}

Sumber :SPSS 25(2019)

Berdasarkan output tersebut, terjadi penurunan nilai antara 2 Log Likehood awal dan akhir sebesar 34.100. Penurunan likelihood ini menunjukkan model regresi yang lebih baik atau dengan kata lain model yang dihipotesiskan fit dengan data.

\subsection{Koefisien Determinasi}

Koefisien determinasi (Nagelkerke R Square) digunakan untuk mengetahui seberapa besar kontribusi variabel independen terhadap variabel dependen. Koefisien determinasi pada regresi logistik dapat dilihat pada nilai Nagelkerke R Square sebagai berikut.

\section{Hasil Uji Determinasi}




\begin{tabular}{|c|c|c|}
\hline $\begin{array}{c}-2 \text { Log } \\
\text { likelihood }\end{array}$ & $\begin{array}{c}\text { Cox \& Snell } \\
\text { R Square }\end{array}$ & $\begin{array}{c}\text { Nagelkerke } \\
\text { R Square }\end{array}$ \\
\hline $98.654^{\mathrm{a}}$ & 0,291 & 0,395 \\
\hline
\end{tabular}

Sumber : SPSS 25 (2019)

Berdasarkan hasil tabel 6 menunjukan bahwa nilai Nagelkerke $R$ Square sebesar 0.395. Nilai Nagelkerke R Square menunjukan bahwa $39.5 \%$ probabilitas ketepatan waktu pelaporan keuangan dipengaruhi oleh variabel independen, sisanya sebesar $60.5 \%$ dijelaskan oleh variabel lain diluar model penelitian. Nilai ini mengindikasikan bahwa ada hubungan yang kuat antara prediktor dan prediksi.

\subsection{Uji Kelayakan Model Regresi (Goodnes of Fit Test)}

Kelayakan model regresi bertujuan untuk menilai kesesuaian model dengan data, dinilai dengan menggunakan Hosmer and Lemeshow's Goodness of fit Test yang diukur dengan nilai chi square. Probabilitas signifikansi yang diperoleh kemudian dibandingkan dengan tingkat signifikansi $\alpha$ sebesar 5\%. Hipotesis untuk menilai kelayakan model regresi adalah :

Tabel 6

\begin{tabular}{|c|c|c|}
\hline \multicolumn{1}{|c|}{ Hasil Uji Kelayakan Model Regresi } \\
\hline Chi-square & df & Sig. \\
\hline 3,163 & 8 & 0,924 \\
\hline
\end{tabular}

Sumber : SPSS 25 (2019)

Berdasarkan tabel 7 maka dapat dilihat bahwa dari kriteria kelayakan model yang diuji Hosmer and Lemeshow Test memiliki Chi Square sebesar 3.163 dan nilai signifikansi 0.924. Nilai signifikansi yang lebih besar dari 0,05 menyebabkan hipotesis H0 gagal ditolak. Artinya, tidak diperoleh perbedaan antara data estimasi model regresi logistik dengan data observasi, sehingga model sudah layak dan tepat digunakan. Hal ini dapat diartikan model yang digunakan dalam penelitian secara umum dapat dikatakan sesuai dan layak.

\subsection{Analisis Model Regresi}

Analisis model regresi logistik dilakukan untuk mengetahui sejauh mana profitabilitas terjadinya variabel dependen dapat diprediksi dengan variabel independen. Maka perlu dilakukan analisis ini, di mana hasilnya dapat dilihat pada Tabel 7, Berikut hasil analisis koefisien model regresi logistik. 
Tabel 7

Hasil Analisis Regresi Logistik

\begin{tabular}{|c|c|c|c|c|c|c|}
\hline & B & S.E. & Wald & df & Sig. & $\operatorname{Exp(B)}$ \\
\hline XBRL & 3,434 & 0,792 & 18,814 & 1 & 0,000 & 30,987 \\
\hline DER & 0,107 & 0,133 & 0,640 & 1 & 0,424 & 1,113 \\
\hline ROA & $-0,069$ & 2,581 & 0,001 & 1 & 0,979 & 0,934 \\
\hline Constant & $-2,513$ & 0,852 & 8,694 & 1 & 0,003 & 0,081 \\
\hline
\end{tabular}

Sumber : SPSS 25 (2019)

Dari pengujian persamaan regresi logistik pada Tabel 4.8, maka diperoleh model regresi logistik sebagai berikut :

$$
\text { KW = -2,513 + 3,434 XBRLit }+ \text { 0,107 DER } \text { DE }_{i t} \text { 0,069 ROA } \text { Rit }_{+} e_{i t}
$$

1. Pada variabel XBRL, diperoleh nilai koefisien sebesar 3.434 dengan tanda positif yang berarti apabila pada variabel XBRL meningkat sebesar 1 satuan, maka penerapan XBRL akan meningkat sebesar 3.434 satuan dengan asumsi bahwa variabel independen lain dalam kondisi konstan.

2. Pada variabel DER, diperoleh nilai koefisien sebesar 0.107 dengan tanda positif yang berarti apabila pada variabel DER meningkat sebesar 1 satuan, maka tingkat liabilitas terhadap ekuitas perusahaan akan meningkat sebesar 0.107 satuan dengan asumsi bahwa variabel independen lain dalam kondisi konstan.

3. Pada variabel ROA, diperoleh nilai koefisien sebesar -0.069 dengan tanda negatif yang berarti apabila pada variabel ROA meningkat sebesar 1 satuan, maka kemampuan perusahaan untuk menghasilkan laba bersih dari total asset yang ada akan menurun sebesar 0.069 satuan dengan asumsi bahwa variabel independen lain dalam kondisi konstan.

\subsection{Pembahasan}

\subsubsection{Pengaruh Penerapan XBRL terhadap Ketepatan Waktu Pelaporan Keuangan}

Penerapan XBRL juga sejalan dengan meningkatnya perusahaan yang melaporkan laporan keuangan dengan tepat waktu, pada tahun 2016 hanya 2 perusahaan yang melaporkan laporan keuangan secara tepat waktu, tahun berikutnya meningkat drastis sebanyak 29 yang melaporkan laporan keuangan dengan tepat waktu hingga tahun 2018 sebanyak 30 perusahaan yang tepat waktu dalam melaporkan laporan keuangan perusahaan pada Bursa Efek Indonesia, hal ini menunjukan bahwa penerapan XBRL dapat meningkatkan ketepatan waktu pelaporan keuangan perusahaan.

Arah Positif pada koefisien variabel XBRL menunjukkan bahwa penerapan XBRL dapat meningkatkan atau mempercepat pemrosesan pelaporan keuangan sehingga perushaan dapat tepat waktu dalam melaporkan pelaporan keuangan pada bursa efek Indonesia. Penelitian Baldwin \& Trinkle, (2011) bahwa potensi manfaat dari penerapan XBRL dapat mewujudkan efisiensi dalam hal pemrosesan pelaporan keuangan, penandaan yang sesuai dengan taksomi yang ditetapkan berdasarkan setiap informasi yang relevan dengan pelaporan keuangan dan akan menghasilkan system yang stabil dan konsisten membuat pengumpulan data untuk penyusunan laporan keuangan 
menjadi efisien dan efektif sehingga dapat mempercepat pemrosesan pelaporan keuangan perusahaan.

\subsubsection{Pengaruh DER terhadap Waktu Pelaporan Keuangan}

Hasil uji regresi logistik variabel kontrol DER menunjukkan bahwa debt to equity ratio tidak mempengaruhi ketepatan waktu pelaporan keuangan perusahaan. Hal ini sejalan dengan perhitungan rasio hutang terhadap ekuitas yang dilakukan penulis, bahwa pada skala rasio rendah 0,18 yang mengindikasikan perusahaan mampu menutup kewajiban hutangya, maupun pada skala rasio yang tinggi pada angka 11,06 yang bisa mengindikasikan perusahaan tidak mampu menutup kewajiban hutangnya, menunjukan hal yang sama bahwa sama-sama bisa melaporkan laporan keuangan secara tepat waktu.

Hasil ini sependapat dengan penelitian Dwiyanti (2010) menjelaskan bahwa temuan ini tidak konsisten dengan logika teori dalam penelitian. Hal ini mengindikasikan bahwa baik perusahaan yang tepat waktu maupun perusahaan yang tidak tepat waktu dalam pelaporan keuangannya mengabaikan informasi tentang debt to equity ratio.

\subsubsection{Pengaruh ROA terhadap Ketepatan Waktu Pelaporan Keuangan}

Hasil uji regresi logistik dalam profitabilitas perusahaan yang diukur dengan Return on Asset, menunjukkan bahwa profitabilitas tidak mempengaruhi ketepatan waktu pelaporan keuangan perusahaan. Hasil penelitian ini konsisten dengan hasil penelitian Astuti (2019) dan Nurhasanah \& Harahap (2018) yang menemukan bukti empiris bahwa profitabilitas tidak mempengaruhi ketepatan waktu pelaporan keuangan.

Hasil ini dapat dibuktikan dengan perhitungan tabulasi data penelitian dimana skala rasio profitabilitas pada angka -0,02 yang dapat mengindikasikan perusahaan tersebut tidak efektif dalam mengelola asset untuk menghasilkan laba bersih yang lebih besar, maupun pada skala rasio yang tertinggi dalam tabulasi data penelitian pada angka 0,48 dapat menunjukan bahwa perusahaan dengan skala rasio ROA yang rendah maupun tinggi perusahaan dapat mampu melaporkan laporan keuangan perusahaan dengan tepat waktu.

\section{PENUTUP}

\subsection{Kesimpulan}

Penelitian ini bertujuan untuk menemukan bukti empiris tentang pengaruh penerapan XBRL (extensible business reporting language) terhadap ketepatan waktu pelaporan keuangan perusahaan Indeks LQ45 dengan menggunakan sampel sebanyak 33 perusahaan yang terdaftar indeks LQ45 tiga periode dari tahun 2016, 2017 dan 2018 sehingga didapatkan jumlah sampel (n) sebanyak 99 sampel.

Berdasarkan hasil pengujian regresi logistik dan analisis penelitian, dapat dibuat kesimpulan bahwa peneltian ini memberikan bukti mengenai penerapan XBRL dapat mempercepat proses pelaporan keuangan dengan sehingga meningkatkan ketepatan waktu pelaporan keuangan perusahaan. Hal ini dikarenakan format XBRL dapat dikonversikan ke berbagai format laporan keuangan lainnya, sehingga akan meminimalisir waktu penyebaran informasi keuangan. 


\subsection{Keterbatasan dan Saran}

Penelitian ini memiliki beberapa keterbatasan yang diharapkan dapat membantu peneliti berikutnya yang ingin mengembangkan penelitian ini. Adapun keterbatasan dalam penelitian ini adalah sebagai berikut :

1. Penelitian ini hanya menggunakan sampel perusahaan yang terdaftar pada Indeks LQ45 perusahaan terbuka di Indonesia selama tiga tahun yaitu tahun 2016 sampai dengan 2018. Hal ini disebabkan karena peneliti ingin menguji penerapan XBRL terhadap ketepatan waktu pelaporan keuangan pada indeks LQ45 yang memiliki fundamental perusahaan yang baik pada Bursa Efek Indonesia. Penelitian lebih lanjut diharapkan dapat menggunakan data dengan indeks saham berbeda agar dapat menemukan fenomena yang baru pada indeks saham yang berbeda.

2. Penelitian ini hanya memiliki dua variabel kontrol yaitu Debt to Equity Ratio (DER) dan Return On Asset (ROA). Sehingga diharapkan penelitian lebih lanjut dapat menambahkan lagi variabel kontrol agar dapat mengendalikan pengaruh variabel independen terhadap variabel dependen supaya tidak dipengaruhi oleh faktor luar yang tidak diteliti. 


\section{DAFTAR PUSTAKA}

AHDAN, S. (2015). Extensible Bisnis Reporting Language ( Xbrl ) Sebagai Pertukaran Standar Pelaporan Keuangan Perencanaan Sumber Daya Enterprise Oleh: Syaiful Ahdan Nim: 23215032 Program Studi Teknik Elektro.

Andriana, D., \& Raspati, N. A. (2015). Pengaruh profitabilitas dan kepemilikan publik terhadap ketepatan waktu penyampaian laporan keuangan. Jurnal Riset Akuntansi Dan Keuangan, 3(2), 675-687.

Arnold, V., Bedard, J. C., Phillips, J. R., \& Sutton, S. G. (2012). The impact of tagging qualitative financial information on investor decision making: Implications for XBRL. International Journal of Accounting Information Systems, 13(1), 2-20.

Astuti, C. D. (2007). Faktor Faktor Yang Berpengaruh Terhadap Ketepatan Waktu Pelaporan Keuangan. Jurnal Informasi, Perpajakan, Akuntansi Dan Keuangan Publik, 2(1), 27-42.

Baldwin, A. A., \& Trinkle, B. S. (2011). The impact of XBRL: A Delphi investigation.

Bartley, J., Chen, A. Y. S., \& Taylor, E. Z. (2011). A comparison of XBRL filings to corporate 10Ks-evidence from the voluntary filing program. Accounting Horizons. https://doi.org/10.2308/acch-10028

BEI. (2014). Pengenalan XBRL dan Implementasi XBRL di BEI. Retrieved March 2, 2019, from https://www.idx.co.id/perusahaan-tercatat/xbrl/

Birt, J. L., Muthusamy, K., \& Bir, P. (2017). XBRL and the qualitative characteristics of useful financial information. Accounting Research Journal, 30(01), 107-126.

Boritz, J. E., \& No, W. G. (2009). The SEC's XBRL voluntary filing program on EDGAR: A case for quality assurance. Current Issues in Auditing, 2(2), A36-A50.

Callaghan, J., \& Nehmer, R. (2009). Financial and governance characteristics of voluntary XBRL adopters in the United States. International Journal of Disclosure and Governance, 6(4), 321335.

Chen, S., Harris, L., Li, W., \& Wu, D. (2015). How does XBRL affect the cost of equity capital? Evidence from an emerging market. Journal of International Accounting Research, 14(2), 123145.

Chowdhuri, R., Yoon, V. Y., Redmond, R. T., \& Etudo, U. O. (2014). Ontology based integration of XBRL filings for financial decision making. Decision Support Systems, 68, 64-76.

Connelly, B. L., Certo, S. T., Ireland, R. D., \& Reutzel, C. R. (2011). Signaling theory: A review and assessment. Journal of Management, 37(1), 39-67.

Copeland, T. E., \& Weston, J. F. (1995). Finanzas en administración. 
Dwiyanti, R., \& ARDIYANTO, M. D. (2010). Analisis faktor-faktor yang mempengaruhi ketepatan waktu pelaporan keuangan pada perusahaan manufaktur yang terdaftar di Bursa Efek Indonesia. UNIVERSITAS DIPONEGORO.

Gray, G. L., \& Miller, D. W. (2009). XBRL: Solving real-world problems. International Journal of Disclosure and Governance, 6(3), 207-223.

Hao, L., H. Zhang, J., \& Fang, J. (2014). Does voluntary adoption of XBRL reduce cost of equity capital? International Journal of Accounting and Information Management, 22(2), 86-102.

Harahap, S. N., \& Putri, H. A. H. (2017). ANALISIS PENGARUH ADOPSI XBRL TERHADAP BIAYA UTANG Full. SNA XX, 3(1), 1. https://doi.org/10.22219/jch.v3i1.7739

Ilias, A., \& Ghani, E. K. (2015). Examining the adoption of extensible business reporting language among public listed companies in Malaysia. Procedia Economics and Finance, 28, 32-38.

Indonesia, U. R. (2017). Otoritas Jasa Keuangan. Satistik Perbankan Syariah 2017.

Izzalqurny, T. R. (2016). Extensible Business Reporting Language (XBRL): Analisis rencana penerapan pada Bursa Efek Indonesia (Studi literatur).

Janvrin, D. J., Pinsker, R. E., \& Mascha, M. F. (2013). XBRL-enabled, spreadsheet, or PDF? Factors influencing exclusive user choice of reporting technology. Journal of Information Systems, 27(2), 35-49.

Jensen, M. C., \& Meckling, W. H. (1976). Theory of the firm: Managerial behavior, agency costs and ownership structure. Journal of Financial Economics, 3(4), 305-360.

Li, O. Z., Ni, C., \& Lin, Y. (2012). Does XBRL adoption reduce the cost of equity capital?

Liu, C., Luo, X., Sia, C. L., O'Farrell, G., \& Teo, H. H. (2014). The impact of XBRL adoption in PR China. Decision Support Systems. https://doi.org/10.1016/j.dss.2013.12.003

Malhotra, R., \& Garritt, F. (2004). Extensible business reporting language: The future of e-commercedriven accounting.

Novitasari, S. (2018). Pengaruh penerapan sistem pelaporan keuangan berbasis Extensible Business Reporting Language (XBRL) terhadap Asimetri informasi pada perusahaan yang terdaftar di indeks LQ45 BEI periode 2014-2017. Universitas Islam Negeri Maulana Malik Ibrahim.

Nurhasanah, N., \& Harahap, S. N. (2018). Pengaruh Penerapan Xbrl Terhadap Cost of Equity Perusahaan Terbuka Di. SNA XXI, 26.

Pinsker, R., \& Li, S. (2009). Costs and benefits of XBRL adoption: Early evidence. Communications of the ACM, 51(3), 47-50.

Pinsker, R., \& Wheeler, P. (2009). Nonprofessional investors' perceptions of the efficiency and effectiveness of XBRL-enabled financial statement analysis and of firms providing XBRL- 
formatted information. International Journal of Disclosure and Governance, 6(3), 241-261. https://doi.org/10.1057/jdg.2009.6

Ra, C.-W., \& Lee, H.-Y. (2018). XBRL Adoption, Information Asymmetry, Cost of Capital, and Reporting Lags. IBusiness, 10(03), 93.

Steenkamp, L. P., \& Nel, G. F. (2012). The adoption of XBRL in South Africa: an empirical study. The Electronic Library, 30(3), 409-425.

XBRL International. (2000). An Introduction to XBRL | XBRL. Retrieved April 1, 2019, from https://www.xbrl.org/the-standard/what/an-introduction-to-xbrl/

Yoon, H., Zo, H., \& Ciganek, A. P. (2011). Does XBRL adoption reduce information asymmetry? Journal of Business Research. https://doi.org/10.1016/j.jbusres.2010.01.008 
